\title{
MAKNA KERJA SEBAGAI TENAGA KESEJAHTERAAN SOSIAL KECAMATAN (TKSK) DI LINGKUNGAN DINAS SOSIAL SITUBONDO JAWA TIMUR
}

\author{
Nuril Endi Rahman', Hendrie Adjie Kusworo² \\ 1,2Departemen Pembangunan Sosial dan Kesejahteraan, Fakultas Ilmu Sosial dan Ilmu \\ Politik, Universitas Gadjah Mada, Yogyakarta \\ nuril.endy@gmail.com
}

\begin{abstract}
ABSTRAK
Tenaga Kesejahteraan Sosial Kecamatan (TKSK) merupakan tenaga non profesional yang direkrut dari unsur tokoh masyarakat setempat, dalam rangka menyukseskan penyelenggaraan program kesejahteraan sosial di tingkat kecamatan. Bekerja sebagai TKSK yang memiliki keterbatasan materi dan karier, serta tantangan yang sulit dalam praktiknya merupakan sebuah pekerjaan yang menyimpan makna subjektif yang dialami oleh masingmasing TKSK. Penelitian ini bertujuan untuk mengungkap makna subjektif dari para TKSK di Kabupaten Situbondo dalam menjalani pekerjaannya sebagai pendamping PMKS. Penelitian ini menggunakan metode penelitian kualitatif deskriptif, pengumpulan data dilakukan dengan cara wawancara mendalam, observasi partisipatif, dan studi dokumen. Analisis data bersifat induktif yang dilakukan sejak proses pengumpulan data. Analisis dalam penelitian menunjukkan bahwa, Para TKSK di Dinas Sosial Situbondo menjalankan pekerjaannya berdasarkan: 1.Motif kemanusiaan dan religiusitas, di mana pekerjaannya merupakan pekerjaan yang mulia dan atas dasar panggilan untuk mendampingi para Penyandang Masalah Kesejahteraan Sosial yang merupakan kelompok marginal dan mengalami kondisi pra sejahtera, serta tidak memiliki akses terhadap program-program kesejahteraan sosial, para TKSK juga menganggap pekerjaannya adalah sebagai sarana ibadah. 2. Motif ekonomi, para TKSK menjalani pekerjaan adalah bagian dari memenuhi kebutuhan hidupnya. 3. Motif mengejar karier, para TKSK di Dinas Sosial Situbondo menjalani pekerjaan tidak terlepas dari keinginan mencapai karier yang diinginkan dalam pekerjaannya, para TKSK mengharapkan statusnya untuk disetarakan dengan Pegawai Negeri Sipil (PNS). Makna kerja sebagai calling, lebih melekat pada TKSK yang memiliki masa pengabdian 5-10 tahun, sedangkan para TKSK non-aktif lebih dominan memaknai pekrjaannya sebagai sarana pemenuhan kebutuhan hidup dan mengejar karier.
\end{abstract}

Kata kunci: Makna kerja, Tenaga Kesejahteraan Sosial Kecamatan, Pendamping PMKS

\section{ABSTRACT}

Tenaga Kesejahteraan Sosial Kecamatan (TKSK), or sub-district government social workers are non-professional staffs recruited from local community leaders in order to succeed the implementation of social welfare programs at the district level.. Working as a TKSK that has material and carrer limitations, and difficult challenges in practice is a job that stores the subjective meaning experienced by each TKSK. This study aims to uncover the subjective meaning of the TKSK in Situbondo Regency in carrying out their work as a facilitators for PMKS. This research uses descriptive qualitative research methods, data collections by indepth interviews, participatory obervation, and document studies. Data analysis is inductive since the data collection procces. Analysis in the research shows that, the TKSK in Situbondo 
Regency carry out their work based on: 1. Humanitarian and religious motives, where the work is work that helps to vulnerable groups who experience poor conditions and do not have acces to social welfare programes, the TKSK considers their work as means of worship. 2. Economic motives, the TKSK undergoing work is part of meeting their needs. 3. Motives for pursuing a carrer, the TKSK in Situbondo Regency undergo their work is inseparable from to desire to achieve the desired carrer in their work, the TKSK expects their status to be equalized with the Civil Servants or PNS. The meaning of work as a calling is more attached to the TKSK which has a service period of 5-10 years, while the non-active TKSK are more dominant in interpreting their work as a means of meeting their needs and pursuing a carrer.

Keyword: Meaning of Work, Tenaga Kesejahteraan Sosial Kecamatan, Social Facilitators for PMKS

\section{PENDAHULUAN}

Keberadaan tenaga kesejahteraan sosial sebagai pendamping sosial, berperan sangat strategis dalam menangani masalah sosial. Keberhasilan program Kementerian Sosial dalam pembangunan kesejahteraan sosial salah satunya ditentukan oleh kompetensi pendamping sosial yang bertugas mendampingi program-program Kementerian Sosial di masyarakat (Suryani\&Purnama,2017:69).

Salah satu fokus aktifitas dalam pekerjaan pendampingan sosial ialah, pendampingan pada Penyandang Masalah Kesejahteraan Sosial (PMKS) yang digagas dalam kebijakan Kementerian Sosial RI, dalam rangka penanganan masalah kesejahteraan sosial. Sebagai wujud pelaksanaannya kemudian dibentuk tenaga pendamping bagi PMKS yakni Tenaga Kesejahteraan Sosial Kecamatan (TKSK) yang dibentuk pada tahun 2009, yang mengacu pada Undang-Undang Nomor 11 tahun 2009 tentang Kesejahteraan Sosial.

Secara umum tugas TKSK dalam penyelenggaraan kesejahteraan sosial meliputi, kegiatan pemetaan sosial terhadap PMKS, dan Potensi Sumber Kesejahteraan Sosial (PSKS), melakukan koordinasi dan sinergi dengan sumber kesejahteraan sosial dalam rangka menyelenggarakan program kesejahteraan sosial, melakukan kegiatan penyuluhan dan bimbingan, serta mengembangkan partisipasi masyarakat dan berbagai pihak dalam rangka menyelenggarakan kesejahteraan sosial. Berdasarkan data Direktorat Pemberdayaan Keluarga dan Kelembagaan Sosial Kementerian
Sosial, jumlah tenaga TKSK di Indonesia pada tahun 2013 mencapai 5.267 orang, yang tersebar di seluruh kecamatan di Indonesia (Panduan TKSK Kemensos RI,2013:23).

Keberadaan para TKSK di Kabupaten Situbondo dimulai sejak tahun 2009, di mana mayoritas berasal dari unsur masyarakat setempat dengan latar belakang pendidikan SMA/sederajat dan sarjana dari semua bidang ilmu. Fakta dilapangan saat ini, para TKSK terus melakukan pendampingan terhadap PMKS ditengah keterbatasan materi dan minimnya fasilitas yang menunjang tugas mereka, seperti alat transportasi. Konsistensi para TKSK di Dinas Sosial Situbondo dalam menjalankan pekerjaannya sebagai pendamping PMKS, merupakan sebuah aktifitas yang penuh makna bagi para TKSK di mana sejak tahun 2009 menjalani pekerjaan dengan kendala keterbatasan materi dan pendukung kerja, serta lemahnya legitimasi baik dari Kementerian Sosial maupun Dinas Sosial Provinsi Jawa Timur dan Dinas Sosial Situbondo, yang hingga saat ini posisinya masih dianggap sebagai relawan dalam penyelenggaraan kesejahteraan sosial, kendati perannya sangat vital khususnya dalam penanganan pada PMKS.

Menurut Wrzesniewski (2003) makna kerja merupakan pemahaman mendalam seseorang akan suatu pekerjaan, di mana dalam pekerjaan tersebut tersimpan nilai-nilai, serta dijalankan atas dasar perasaan senang. Dengan segala keterbatasan yang ada sebagai pendamping PMKS, para TKSK di Dinas Sosial Situbondo menyimpan makna subjektif terkait pekerjaannya, di mana di dalam pekerjaannya 
tersebut terdapat nilai-nilai yang melekat dan terwujud dalam aktifitas mereka dalam menjalankan tugas-tugas pendampingannya.

Kehadiran dan peran seorang TKSK pada saat ini semakin dibutuhkan, mengingat dimensi permasalahan yang semakin kompleks dialami oleh para PMKS, yang merupakan kelompok marginal dan kurang memiliki akses terhadap program dan pelayanan kesejahteraan sosial. TKSK sebagai 'ujung tombak' dalam penyelenggaraan kesejahteraan sosial di tingkat kecamatan, yang berperan sebagai seorang pendamping dituntut untuk memiliki pengabdian yang kuat dan total dalam rangka menyukseskan penyelenggaraan program-program kesejahteraan sosial yang menjadi agenda besar dari Kementerian Sosial. Makna kerja yang memuat nilai-nilai, harapan, dan tujuan yang melekat pada masing-masing TKSK, merupakan hal penting sehingga perlu dieksplorasi guna memahami kapasitas para TKSK terutama di Kabupaten Situbondo, yang pada saat ini masih dihadapkan pada persoalan maraknya PMKS yang belum mendapatkan akses terhadap programprogram kesejahteraan sosial, disamping para TKSK yang memiliki keterbatasan materi dan karier dalam menjalankan pekerjaannya sebagai pendamping PMKS. Berdasarkan uraian permasalahan tersebut pertanyaan utama yang diajukan dalam penelitian ini adalah: Bagaimana para TKSK di Dinas Sosial Situbondo memaknai pekerjaannya sebagai pendamping PMKS?

\section{METODE}

Penelitian ini merupakan jenis
penelitian kualitatif menurut Creswell (2002:4) pendekatan kualitatif merupakan suatu pendekatan penelitian yang mempertimbangkan realitas subyektif yang dianut oleh objek penelitian. Penelitian ini menggunakan pendekatan deskriptif yang bertujuan, untuk menjelaskan pemaknaan para TKSK dalam memaknai pekerjaannya sebagai pendamping PMKS. Deskripsi yang disajikan merupakan interpretasi dari informasi yang didapatkan dari informan yakni para TKSK di Dinas Sosial Situbondo. Informan dalam penelitian berdasarkan kriteria yang ditetapkan, kriteria pertama ditentukan atas dasar durasi TKSK yang menjalani pekerjaan dalam kurun waktu 5-10 tahun, sedangkan kriteria kedua merupakan TKSK dengan masa kerja kurang dari 5 tahun. Alasan pemilihan informan dengan kriteria tersebut ialah, untuk melihat keragaman makna dari masing-masing informan terhadap pekerjaannya. Sedangkan informan tambahan yakni kepala seksie Pemberdayaan Sosial Dinas Sosial Situbondo, sebagai penanggung jawab para TKSK.

\section{Pengumpulan data dalam penelitian} melalui wawancara mendalam, observasi partisipatif, dan telaah laporan kinerja TKSK serta pedoman umum/mekanisme kerja TKSK. Analisis data dilakukan secara induktif, yang dilakukan bersamaan dengan proses pengumpulan data dilapangan, kemudian peneliti mengabstraksikan konsep-konsep yang dikembangkan berdasarkan cerita/informasi dari para informan. Makna subjektif yang dialami oleh para informan, kemudian diidentifikasi melalui cerita atau kalimat dari informan, cerita atau informasi dari para informan tersebut kemudian di kontekstualisasikan dalam pemaknaan menjalani pekerjaan sebagai TKSK.

\section{HASIL DAN PEMBAHASAN}

\section{Motif Kemanusiaan dan Religiusitas dalam Menjalani Pekerjaan}

Pemaknaan para TKSK di lingkungan Dinas Sosial Situbondo terkait pekerjaannya, yang dimaknai sebagai tugas kemanusiaan, merupakan hasil refleksi atas pengalaman yang sebelumnya sering menjumpai PMKS dalam kehidupan sehari-hari, sehingga dari pengalaman pengamatan terhadap PMKS tersebut memicu persepsi bahwa, para PMKS perlu mendapatkan pertolongan untuk mempromosikan kesejahteraan para PMKS, dan dari pengalaman tersebut memunculkan orientasi pada TKSK untuk menekuni pekerjaan sebagai pendamping PMKS melalui kebijakan pemerintah. Para TKSK memandang PMKS ialah sebagai individu yang mengalami 'pengabaian' atau marginalisasi oleh lingkungan sosialnya sehingga mengalami keterlantaran dan tidak memiliki akses pada program-program kesejahteraan sosial, sehingga para TKSK memandang orientasi pekerjaannya ialah untuk membantu para PMKS terbebas dari keterlantaran dan keterpinggiran. Dalam konsep filantropi sosial yang dijelaskan oleh Firdaus (dalam Hurairah,2011:124), aksi filantropi sosial oleh individu dan kelompok seperti, solidaritas dan tindakan sukarela dilandasi oleh perspektif moral, kebudayaan, dan nilai religius di mana 
ketiga stimulus tersebut terinternalisasi kedalam tindakan yang bersifat filantropi.

Secara umum motif filantropi yang melekat pada masing-masing TKSK di Kabupaten Situbondo, merupakan stimulus dari adanya penyelenggaraan program kesejahteraan sosial yang digagas oleh Kementerian sosial sejak tahun 2009 di level kecamatan. Meskipun pada awalnya pihak Kementerian Sosial memakai kata Manajer Sosial Kecamatan (MASKOT), di mana para TKSK mempersepsikannya sebagai pekerjaan yang memiliki jenjang karier dan honor yang layak, namun ketidaksesuaian harapan tersebut pada akhirnya memicu para TKSK secara perlahan memiliki kepekaan sosial dan kesetiakawanan sosial, karena dipicu oleh ikatan kerja yang agenda besarnya ialah program penyelenggaraan kesejahteraan sosial. Sebagaimana yang dijelaskan oleh Fauzia dkk (2018:9), praktik-praktik filantropi yang pada saat ini menjadi fenomena, banyak dilakukan pada program-program sosial kemanusiaan yang tujuannya untuk pengembangan masyarakat. Motif filantropi dalam konteks pekerjaan sebagai TKSK yang merupakan aktifitas pertolongan dan didasarkan pada mekanisme kerja, berbeda dengan strategi karitatif yang aktifitas pertolongannya bersifat sporadis dan temporal, serta tidak ada mekanisme yang mengatur aktifitasnya. Dalam menjalankan aktifitas pendampingannya kepada PMKS yang merupakan kelompok marginal, dan tidak memiliki akses untuk meningkatkan derajat hidupnya, TKSK kemudian bergerak atas dasar motif filantropi yang dikombinasikan dengan mekanisme pendampingan yang ter struktur guna menghadirkan keberfungsian sosial sebagai tujuan dari program.

Sebagai sebuah gerakan kemanusiaan, filantropi sosial terwujud kedalam beberapa strategi, sebagaimana yang dijelaskan oleh Tamim (2011:52) pertama, strategi karitas; merupakan strategi pengentasan kemiskinan melalui pemberianpemberian bantuan berupa bahan makanan, material maupun uang tunai. Strategi karitas ini pada level praktinya menyentuh level kehidupan dengan bentuk pelayanan hidup. Kedua, strategi pemberdayaan yang merupakan strategi pengentasan kemiskinan dengan menumbuhkan kesadaran, kemampuan, dan kemandirian kepada kelompok powerless. Dalam konteks motif yang dimiliki oleh para TKSK dalam menekuni pekerjaannya, strategi pemberdayaan merupakan yang paling dominan dalam praktik pendampingannya, daripada strategi karitas. Strategi pemberdayaan lebih dominan mengingat mandatori sebagai TKSK ialah sebagai dinamisator, motivator, fasilitator, dan koordinator sehingga aktifitas pemberdayaan seperti memfasilitasi para eks WTS untuk mendapatkan program Usaha Ekonomi Produktif serta pemberian motivasi secara langsung, merupakan upaya untuk menumbuhkan kemandirian kepada PMKS.

Menjalani pekerjaan dalam kurun waktu yang lama, dengan jaminan materi yang minim, merupakan wujud dari menjalankan pekerjaan atas panggilan terutama untuk membantu sesama. Makna kerja sebagai calling (panggilan) dijelaskan lebih eksplisit oleh Wrzesniewski\&Roso (dalam Amalia,2015:30) secara tradisional, carrer calling dipahami sebagai tujuan pekerjaan yang memiliki hubungan dengan tuhan, esensinya pekerjaan itu bermuara pada konteks sosial dalam jalan tuhan. Sementara dalam visi modern, carrer calling tidak hanya dikaitkan dengan tuhan. Makna sosial masih tetap bertahan sehingga pekerjaan yang dilakukan mempunyai tujuan sosial untuk mendapatkan kepuasan tertentu. Para TKSK di Dinas Sosial Situbondo, yang memiliki masa kerja 5-10 tahun memaknai pekerjaannya yang lebih banyak menghabiskan waktu dengan para PMKS, dianggap sebagai sarana ibadah serta pengejewantahan nilai-nilai religius yang dianut oleh para TKSK. Kendati pekerjaannya bukan sebuah pekerjaan yang menjanjikan karier yang jelas, namun para TKSK menganggap pekerjaannya memiliki kontribusi dalam mempromosikan kesejahteraan para PMKS, melalui programprogram kesejahteraan sosial dari pemerintah.

Menjalani pekerjaan sebagai TKSK
berdasarkan motif kemanusiaan dan
religiusitas, merupakan panggilan bagi para
TKSK untuk mengabdikan diri pada tugas-
tugas kemanusiaan, dalam hal ini
mendampingi para PMKS yang merupakan
individu, kelompok dan komunitas yang
mengalami keterpinggiran. Sebagaimana
dijelaskan oleh Dik\&Duffy (dalam
Yuniswara\&Handoyo,2013:02) calling sebagai
suatu panggilan transendental, yang dialami
dengan sumber dari luar diri, untuk mendekati
peran hidup tertentu yang bertujuan untuk

Menjalani pekerjaan sebagai TKSK berdasarkan motif kemanusiaan dan religiusitas, merupakan panggilan bagi para TKSK untuk mengabdikan diri pada tugasmendampingi para PMKS yang merupakan individu, kelompok dan komunitas yang mengalami keterpinggiran. Sebagaimana dijelaskan oleh Dik\&Duffy (dalam Yuniswara\&Handoyo,2013:02) calling sebagai cuatu panggilan transendental, yang dialami peran hidup tertentu yang bertujuan untuk 
menunjukkan atau menghasilkan suatu tujuan atau kebermaknaan dengan berpegang pada nilai-nilai yang diarahkan dan ditujukan bagi orang lain sebagai sumber utama motivasi. Bagi para TKSK yang memiliki masa pengabdian selama 5-10 tahun, menjalani pekerjaan yang secara materi tergolong minim untuk memenuhi kebutuhan hidup, bukanlah sebuah halangan untuk tetap menjalani tugastugas pendampingannya dengan perasaan senang. Karena bekerja mendampingi PMKS adalah sarana ibadah dan menganggap pekerjaannya memiliki kontribusi bagi para PMKS.

Bekerja sebagai TKSK yang berbasis motif filantropi dan dijalankan dengan rasa ikhlas serta kesabaran, secara perlahan menghadirkan penghargaan pada TKSK, kepercayaan institusi yang menjadikannya sebagai pekerja masyarakat yang 'multi guna' pada akhirnya diikuti dengan perhatian kesejahteraan para TKSK, dengan memberikan pekerjaan sampingan yang juga berkaitan dengan isu-isu kesejahteraan masyarakat. Dengan demikian, aspek filantropi mengalami dinamika dari pengertian awalnya yang diartikan sebagai wujud tindakan kesukarelawanan atau karitatif, kemudian bertransformasi menjadi basis penguatan kerja, yang dielaborasi dengan strategi pendampingan sosial yang di dalam praktiknya para TKSK memainkan peran sebagai dinamisator, fasilitator/motivator, dan pendidik bagi para Penyandang Masalah Kesejahteraan Sosial (PMKS) yang dikategorikan sebagai kelompok marginal dan mengalami kondisi powerless.

\section{Motif Ekonomi dalam Menjalani Pekerjaan}

Nilai-nilai yang melekat dalam pekerjaan TKSK sebagai pendamping PMKS, yakni nilai kemanusiaan dan nilai religi kurang melekat pada TKSK non-aktif. Rendahnya honorarium/tali asih yang diterima, merupakan alasan utama oleh para TKSK, sehingga memaknai pekerjaannya sebagai pendamping PMKS dianggap pekerjaan yang kurang mempunyai masa depan. Orientasi ekonomi/materi dalam bekerja memang tidak sepenuhnya negatif, namun orientasi ekonomi perlu diseimbangkan dengan aspek-aspek non-materi, yang menjadi penguat bagi para TKSK untuk melaksanakan pekerjaannya dengan baik. Anshori (2013:159), menjelaskan bahwa kerja adalah cara untuk menghasilkan uang dan meningkatkan kesejahteraan, jadi orang bekerja bukan hanya sekedar mendapatkan uang namun juga menjadi bagian dari kehidupan sosial, penerimaan, penghargaan dan sebagainya yang meningkatkan produktifitas seseorang dalam bekerja. Alasan honorarium/tali asih yang rendah memang sebuah fakta, di mana dengan honorarium/ tali asih yang diterima tidak mampu untuk memenuhi kebutuhan hidup. Namun lemahnya nilai filantropi pada TKSK non-aktif, yang menjadikan mereka tidak serius dalam menjalankan tugas pendampingannya dan lebih mengutamakan pekerjaan lain, bahkan memundurkan diri. Para TKSK non-aktif, tidak memandang pekerjaannya sebagai nilai-nilai yang berarti dalam kehidupan sosial, serta tidak memerlukan penghargaan selain penghargaan yang sifatnya materiil.

Faktor lain yang mempengaruhi keterikatan kerja yaitu sumber pribadi. Makna kerja merupakan pemaknaan individu terhadap pekerjaannya yang diantaranya sebagai job, carrer atau calling (Wrzesniewski,1997). Pemaknaan para TKSK non-aktif di tiga kecamatan yakni Mlandingan, Suboh dan Banyuglugur memaknai pekerjaan sebagai aktifitas kerja pada umumnya yang bertujuan untuk memperoleh upah yang layak guna memenuhi kebutuhan hidup, dan sebagai sarana untuk memperoleh karir yang bagus sebagai wujud pencapaian dari karier/status sosial. Para TKSK non-aktif tidak memaknai pekerjaannya sebagai suatu panggilan kemanusiaan, seperti yang dialami oleh para TKSK yang telah mengabdi selama 5- 10 tahun, yang menganggap bahwa bekerja mendampingi PMKS adalah sebagai sarana ibadah dan panggilan kemanusiaan, sehingga harapan akan pencapaian ekonomi yang tidak tercapai, bukan sebuah alasan untuk tidak mengabdikan dirinya secara total.

Motif ekonomi yang merupakan motivasi utama TKSK non-aktif, yang merupakan pemuas kebutuhan hidupnya, merupakan hal yang tidak tercapai ketika menjalani pekerjaan, sehingga memilih mencari alternatif pekerjaan lain yang lebih mampu memenuhi kebutuhan hidupnya. Seperti yang dijelaskan oleh Kartono (2002:154), frustasi yang diakibatkan oleh terhalangnya pemuas suatu kebutuhan, tidak seluruhnya disebabkan oleh situasi objektif 
dari individu, akan tetapi lebih banyak oleh respon-respon rasional dan emosionalnya. Perasaan frustasi yang dialami oleh TKSK nonaktif di Kabupaten Situbondo, merupakan wujud ketidaksesuaian harapan dalam menjalani pekerjaan, harapan akan honor yang layak merupakan alasan rasional untuk memenuhi kebutuhan hidup, sehingga ketika hal tersebut tidak terpenuhi lebih memilih alternatif pekerjaan lain untuk memperoleh kepuasan ekonomi yang lebih layak, sebagaimana dijelaskan oleh Suradi\&Mujiyadi (2018:135) honorarium memang memliki korelasi yang lemah, karena banyak pendamping sosial yang bekerja karena panggilan kemanusiaan. Namun demikian mereka memiliki daftar kebutuhan hidup yang harus dipenuhi. Bagi para TKSK yang memiliki masa pengabdian 5-10 tahun, cenderung memiliki respon rasional dan emosional yang seimbang, yang menganggap honorarium yang diterimanya adalah hal yang patut diterima dan disyukuri, serta tidak berhenti untuk mendedikasikan dirinya mendampingi para PMKS untuk keluar dari kondisi pra sejahtera.

\section{Motif Mengejar Karier dalam Menjalani Pekerjaan}

Menjalani sebuah pekerjaan tidak terlepas dari memperjuangkan karier, dalam hal ini para TKSK di Dinas Sosial Situbondo memiliki motivasi tinggi untuk memperoleh karier yang diinginkan dalam bekerja sebagai TKSK. Para TKSK mengharapkan statusnya dapat disejajarkan dengan Pegawai Negeri Sipil (PNS), harapan tersebut didasarkan pada tugas-tugas pendampingan yang berat dan memiliki tantangan besar, serta adanya pengabdian yang panjang dengan keterbatasan materi. Sehingga bagi para TKSK yang telah mengabdi selama 5-10 tahun harapan akan pencapaian karier yang lebih jelas patut untuk diterima. Namun bagi para TKSK non-aktif, ketiadaan jenjang karier yang jelas membuat mereka 'setengah hati' dalam menjalankan pekerjaannya, sehingga berdampak pada kinerja yang dinilai tidak memuaskan oleh dinas sosial, dan di nonaktifkan.

Motivasi kerja yang dominan berorientasi pada pemenuhan ekonomi dan mengejar karier, merupakan faktor utama bagi para TKSK non-aktif merasakan frustasi dalam menjalani pekerjaannya. Menurut Kartono
(2002:147) aspek pertama dari kerja yang perlu dibahas ialah motivasi. Motivasi bekerja tidak hanya berwujud kebutuhan ekonomi saja, tetapi bisa juga dalam bentuk kebutuhan psikis untuk berbuat. Rasa frustasi yang dirasakan oleh TKSK non-aktif di Kabupaten Situbondo, merupakan wujud dari dominannya motivasi ekonomi dan status sosial, namun aspek psikis seperti, kecintaan atau perasaan senang dalam menjalani pekerjaan seperti hal nya para TKSK yang telah mengabdi selama 510 tahun, tidak melekat pada TKSK non-aktif sehingga mereka cenderung memaknai secara negatif pekerjaannya. Para TKSK non-aktif selama menjalani pekerjaannya, hanya bertujuan untuk memenuhi kebutuhan hidup, dan mencapai sebuah karier sesuai dengan yang diharapkan. Seperti yang dijelaskan oleh Goran (2016:211) apabila pekerja memaknai pekerjaannya karier dan sebatas pekerjaan, maka pekerja tersebut menunjukkan rendahnya panggilan (lack of calling) terhadap pekerjaan yang dilakukannya. Panggilan untuk mengabdikan diri pada tugas-tugas kemanusiaan, tidak melekat pada TKSK nonaktif sehingga ketika harapan dalam pekerjaan yang tidak tercapai pada akhirnya membuat mereka tidak secara total menjalankan tugastugas pendampingannya.

Berbeda dengan para TKSK yang telah mengabdikan diri selama 5-10 tahun, di mana motif kemanusiaan dan religiusitas yang melekat membuat mereka merasa senang dan loyal dalam menjalani pekerjaannya atas panggilan kemanusiaan dan nilai-nilai religius, kendati harpan akan karier yang diinginkan agar statusnya disejajarkan dengan PNS belum tercapai, namun tetap konsisten mengabdikan dirinya, seperti yang dijelaskan oleh Goran (2016:211) Pekerja yang memaknai pekerjaannya sebagai panggilan dan tidak berfokus pada karier atau finansial, tetapi pada pengertian (meaning) dan pemenuhan dalam hasil kerja mereka. Mereka percaya bahwa kontribusi kerja mereka untuk menjadi yang terbaik dan membuat dunia sebagai tempat yang nyaman. Para TKSK yang telah mengabdi selama 5-10 tahun, tidak menjadikan faktor keterbatasan materi dan karier dalam pekerjaan sebagai penghalang untuk tetap mendedikasikan dirinya sebagai pendamping PMKS, dan memaknai bahwa setiap tugas-tugas pendampingan mereka memiliki nilai-nilai tersendiri, yang tidak hanya diukur dengan ganjaran honor yang tinggi ataupun karier. Sementara itu para TKSK non- 
aktif memiliki pemaknaan subjektif mengenai pekerjaannya, pandangan dari mereka adalah, dengan honor yang tinggi dan karier yang jelas, merupakan indikator dalam mencapai kinerja yang optimal. Seperti yang dijelaskan oleh Kartono (2002) bahwa seseorang bekerja tidak terlepas dari mengejar karier, peranan dan status. Selain memandang penting besaran gaji, faktor karier dan status sosial merupakan tujuan utama seseorang dalam menjalani pekerjaan. Bagi para TKSK non-aktif di Kabupaten Situbondo, faktor karier dan status sosial serta honorarium yang layak adalah faktor dominan dalam menjalani pekerjaan, sehingga mengenyampingkan nilainilai kemanusiaan yang terkandung dalam pekerjaan.

\section{Refleksi Hasil Penelitian}

Memaknai sebuah pekerjaan merupakan hal yang subjektif, masing-masing individu memiliki nilai-nilai, tujuan, dan harapan yang beragam dalam kaitannya dengan pekerjaan. Pemaknaan pekerjaan oleh para TKSK terdapat kontradiksi, para TKSK yang telah mengabdi selama kurun waktu 510 tahun dan memiliki latar belakang sebagai anggota karang taruna, memaknai pekerjaannya sebagai pekerjaan yang mulia dan berkontribusi dalam penyelenggaraan kesejahteraan sosial di tingkat kecamatan, motif filantropi yang melekat kepada TKSK yang memiliki masa pengabdian 5-10 tahun telah menjadi basis moral yang menguatkan mereka dalam menjalani pekerjaannya, kendati mengalami keterbatasan materi. Menjalani pekerjaan berdasarkan motif filantropi merupakan sebuah panggilan, yang berasakan nilai-nilai religius maupun kemanusiaan seperti penjelasan Dik\&Duffy (dalam Yuniswara\&Handoyo,2013:02) membagi calling kedalam tiga dimensi. Pertama adanya motivasi untuk menjalani peran hidup tertentu, dalam hal ini motivasi berasal dari tuhan hingga kebutuhan sosial yang di masyarakat. Kedua kesadaran akan tujuan dan pemaknaan aktifitas seseorang dalam peran hidup tertentu. Ketiga kontribusi positif seseorang pada kesejahteraan masyarakat baik secara langsung atau tidak. Para TKSK yang menjalani atas panggilan kemanusiaan dan berdasarkan nilai-nilai religius, memaknai pekerjaannya sebagai sebuah pengabdian untuk membantu para PMKS yang merupakan kelompok marginal, kendati dengan keterbatasan honorarium/tali asih serta jaminan karier yang tidak pasti, namun tetap menjalankan aktifitas pendampingannya dengan perasaan senang. Para TKSK menganggap pekerjaannya adalah sebagai sarana ibadah mereka yang memiliki kontribusi, untuk mempromosikan kesejahtreraan para PMKS.

Sementara para TKSK non-aktif memaknai pekerjaannya sebagai pekerjaan untuk mengejar materi dan karier, guna memenuhi kebutuhan hidup dan mencapai status sosial. Para TKSK non-aktif memandang bahwa tugas-tugas pendampingan terhadap PMKS merupakan pekerjaan yang sangat berat dan kompleks, dan tidak seimbang dengan honorarium/tali asih yang diterimanya, sehingga mereka menganggap bahwa pekerjaannya hanyalah pekerjaan sampingan yang bukan menjadi prioritasnya. Sebagaimana dijelaskan oleh Wrzesniewski (1997) faktor intrinsik dalam makna kerja meliputi job, carrer, dan calling. Bagi para TKSK non-aktif, memilih bekerja sebagai TKSK adalah sebagai tuntutan untuk memenuhi kebuthan hidup, dan sebagai sarana untuk mengejar karier atau karier guna memperoleh status sosial. Sementara aspek calling atau panggilan kemanusiaan tidak melekat dalam diri TKSK non-aktif, sehingga seringkali mengabaikan tugas-tugas pendampingan pada PMKS dan lebih memprioritaskan pekerjaan lain. Dalam penjelasan Kartono (2002) status, peranan dan karier merupakan unsur pendorong dalam pekerjaan yang saling bertautan, peranan dalam pekerjaan yang sesuai dengan harapan merupakan sarana untuk memperoleh karier (kehormatan, derajat kebesaran dan kemuliaan), dalam hal ini mendapatkan pekerjaan yang memiliki gaji yang layak dan setara dengan PNS, dan hal tersebut adalah motivasi bagi para TKSK nonaktif dalam menjalani pekerjaannya.

Makna kerja mencakup kepercayaan kita tentang peran kerja dalam kehidupan, dan merefleksikannya dalam perasaan terkait pekerjaan, perilaku dalam bekerja, dan tipetipe tujuan yang diperjuangkan dalam pekerjaan (Wrzeniewski dalam Puspita,2012:6). Makna negatif para TKSK non-aktif dalam menjalani pekerjaannya, merupakan wujud dari perasaan tidak bahagia dan frustasi dalam menjalani pekerjaan. Tujuan memperoleh materi dan karier yang dominan dalam bekerja merupakan faktor pemicu pemaknaan kerja yang negatif, dan 
memandang bekerja sebagai pendamping PMKS tidak menjanjikan masa depan yang baik, di mana kondisi tersebut kontradiksi dengan apa yang dialami oleh para TKSK yang mengabdi selama 5-10 tahun, dan menjalankan pekerjaan atas dasar tujuan kemanusiaan dan menerapkan nilai-nilai religi yang dianut, kendati ditengah keterbatasan materi dan karier yang belum sesuai dengan harapan. Menjalani pekerjaan sebagai TKSK, yang mendampingi para PMKS dalam rangka mempromosikan kesejahteraannya, merupakan sebuah panggilan untuk membantu sesama dalam hal ini para PMKS, yang merupakan kelompok marginal. Pada akhirnya tujuan dan motif dari menjalankan pekerjaan, menentukan perasaan senang atau tidaknya para TKSK dalam menjalani pekerjaannya, serta aspek panggilan (calling) yang mendasari para TKSK menjalankan pekerjaannya dengan perasaan senang dan memaknai pekerjaannya sebagai pekerjaan, yang memiliki tujuan mulia serta berkontribusi pada PMKS.

\section{KESIMPULAN}

Makna bekerja sebagai $\begin{array}{r}\text { Tenaga } \\ \text { (TKSK), }\end{array}$
Kesejahteraan Sosial Kecamatan motif yakni
dapat disimpulkan menjadi tiga motif
motif kemanusiaan dan religiusitas, motif
ekonomi, dan motif mengejar karier. Pertama
Para TKSK yang memaknai pekerjaannya
sebagai panggilan (calling) untuk mengabdi
kepada sesama manusia dan sebagai sarana
ibadah, adalah para TKSK yang telah
mengabdi selama kurun waktu 5-10 tahun.
Para TKSK yang menjalani pekerjaan atas
dasar motif kemanusiaan dan religiusitas, lebih
memiliki komitmen atau keterikatan kerja yang
kuat, kendati menjalani pekerjaan dengan
keterbatasan materi dan karier. Namun tetap
mendedikasikan dirinya untuk mendampingi
para PMKS, dan menikmati setiap tugas-tugas
pendampingannya. Kedua para TKSK
menjalani pekerjaan tidak terlepas dari motif
ekonomi sebagai alat pemenuhan kebutuhan
hidup, para TKSK di Dinas Sosial Situbondo
mengharapkan perbaikan honorarium/tali asih
yang lebih layak. Ketiga para TKSK di Dinas
Sosial Situbondo dalam menjalani pekerjaan
tidak terlepas dari motif mengejar karier, para
TKSK menginginkan statusnya untuk
disejajarkan dengan PNS. Namun terdapat
perbedaan makna antara di mana TKSK non-
aktif menganggap pekerjaannya sebagai
pekerjaan yang kurang memiliki masa depan,

dan menjadikan pekerjaan sebagai TKSK adalah pekerjaan sampingan yang tidak dijalankan secara total. Sementara para TKSK yang memiliki masa pengabdian 5-10 tahun memaknai pekerjaannya sebagai pekerjaan yang mulia dan berkontribusi bagi sesama manusia, serta lebih memiliki keterikatan kerja yang kuat. Pada akhirnya makna kerja sebagai TKSK merupakan makna subjektif, yang diyakini oleh masing-masing individu.

\section{SARAN}

Sebagai upaya peningkatan kualitas Sumber Daya Manusia, yang berperan dalam penyampaian program-program kesejahteraan sosial. TKSK sebagai salah satu aktor penting yang berperan dalam penyelenggaraan kesejahteraan sosial di tingkat kecamatan, diperlukan mekanisme dan standar baru dalam rekuitmen TKSK ke depan, proses rekruitmen perlu menggabungkan aspek kognitif, psikis dan pengalaman, guna memperoleh TKSK yang memiliki dedikasi kuat dalam bekerja. Perlunya peningkatan kompetensi melalui bimbingan teknis yang dilaksanakan secara intensif dan mendalam, serta dengan materi yang lebih beragam, mengingat kompleksitas permasalahan dan tantangan yang dialami oleh para PMKS semakin beragam. Upaya legitimasi juga diperlukan terutama bagi para TKSK yang memiliki masa pengabdian selama 10 tahun dan memiliki kinerja baik, dalam hal ini pihak Kementerian Sosial perlu memfasilitasi para TKSK yang memiliki pengabdian kuat dan kinerja yang baik untuk di sertifikasi, sebagai wujud penghargaan. Sebagai upaya optimalisasi peran TKSK sebagai pendamping PMKS, perlunya pemfokusan pada bidang dan fungsi sebagai pendamping, dan tidak dilibatkan dalam tugas diluar sebagai pendamping PMKS yang justru mengambat kinerja. Serta Perlunya kegiatan monitoring dan evaluasi, baik dari Kementerian Sosial, dinas sosial provinsi dan kabupaten yang dilakukan secara lebih intensif, sebagai upaya peningkatan kinerja para TKSK.

\section{UCAPAN TERIMAKASIH}

Penulis mengucapkan rasa terimakasih yang sebesar-besarnya kepada para TKSK di Dinas Sosial Situbondo, yang telah bersedia menjadi informan dalam penelitian, rasa terimakasih juga penulis sampaikan kepada pihak Dinas Sosial Situbondo, yang turut memfasilitasi peneliti dalam proses penelitian. 


\begin{tabular}{|l|l|l|l|l|}
\hline Share: Social Work Jurnal & VOLUME: 10 & NOMOR: 2 & HALAMAN: $217-225$ & $\begin{array}{c}\text { ISSN: } 2339-0042(\mathrm{p}) \\
\text { ISSN: } 2528-1577(e) \\
\text { DOI: } 10.24198 / \text { share.v10i2.29920 }\end{array}$ \\
\hline
\end{tabular}

\section{DAFTAR PUSTAKA}

Anshori, Nurani Siti. 2013. Makna Kerja (meaning of work) Suatu Studi Etnografi Abdi Dalem Kraton Ngayogyakarta Hadiningrat Daerah Istimewa Yogyakarta. Jurnal Psikologi Industri dan Organisasi, Volume 2 No.3. 157-162.

Amalia dkk. 2015. Carrer, Calling Dan Psychological Well-Being Pada Petugas Di Lembaga Pemasyarakatan Klas 1 Semarang. Jurnal Empati, Volume 4 (1), 28-34.

Creswell, Jhon W. 2002. Research Design:

Desain Penelitian.KIK Press.Jakarta

Fauzia dkk. (2018). Fenomena Praktik Filantropi Masyarakat Muslim dalam Kerangka Keadilan Sosial di Indonesia. Laporan Hasil Penelitian: Divisi Penelitian Social Trust Fund (STF) UIN Syarief Hidayatullah Jakarta

Goran S,S,Oktavianus. 2016. Hubungan Makna Kerja Panggilan Dengan Keterikatan Kerja Pada Penyiar Radio Di Surabaya. Artikel Prosiding SenasPro 2016.

Hurairah, Abu. 2011. Pengorganisasian dan Pengembangan Masyarakat: Model dan Strategi Pembangunan Berbasis Kerakyatan. Bandung: Humaniora

Kartono, Kartini. 2002. Psikologi Sosial Untuk Manajemen Perusahaan dan Industri. Jakarta: PT. Rajagrafindo
Puspita, D, Monica. 2012. Hubungan Antara Dukungan Sosial dan Makna Kerja Sebagai Panggilan (Calling) dengan Keterikatan Kerja. Jurnal Calyptra Universitas Surabaya Vol.1 No.1 2012

Suryani\&Purnama,Ahmad. 2017. Peran Pendamping KUBE FM Dalam Meningkatkan Kesejahteraan Anggotanya. Jurnal Media Informasi Penelitian Kesejahteraan Sosial, Vol.41, No.1 April 2017, 67-76

Suradi\&Mujiyadi.2018. Kinerja Pendamping Sosial Pada Program Penanganan Kemiskinan Dan Kelompok Rentan Di Kota Tarakan. Jurnal Sosiokonsepsia, Vol.7, No.03 Mei-Agustus 2018.

Tamin, Imron.H. 2011. Peran Filantropi dalam Pengentasan Kemiskinan di dalam Komunitas Lokal. Jurnal Sosiologi Islam, Vol.1 No.1 April 2011

Wrzesniewski, A.E et.al. 1997. Job, Carrer and Calling: People's Relation to Their Work. Journal of Research in Personality. 31 21-23

Wrzesniewski, A.E, Dutton, J.E\&Debebe, G. 2003. Interpersonal Sense making and The Meaning of Work. Research in Organizational Behaviour, 25, 93-135

Yuniswara,E,Oktaviana\&Handoyo,Seger. 2013. Proses Pemaknaan Calling pada Imam Katolik. Jurnal PSIKOLOGI Industri dan Organisasi, Vol.02 No.01, April 2013 